\title{
Rumo a vinte anos do regime de metas para inflação no Brasil (1999/2016): uma análise dos resultados ${ }^{1}$
}

\author{
Ramony Ramos ${ }^{2}$ \\ Alexandre Ottoni Teatini Salles ${ }^{3}$
}

\begin{abstract}
Resumo: O Regime de Metas de Inflação (RMI) é um instrumento de política monetária utilizado em diversos países, desenvolvidos e emergentes, como ferramenta de controle da inflação. Em julho de 1999, após vários ataques especulativos, o Brasil deixou de usar a âncora cambial como principal ferramenta para controle da inflação, e passou a adotar o RMI. Entretanto, alguns autores criticam a implementação deste regime no Brasil e demonstram que ele não tem se mostrado eficaz, tanto no combate à inflação como no suporte ao crescimento econômico do país. Este trabalho pretende fornecer subsídios para o debate sobre os custos e benefícios que este regime tem gerado para a economia brasileira. O objetivo é apresentar os fundamentos e fazer uma avaliação crítica dos resultados do RMI no Brasil no período 1999 a 2016. A análise reveladurante a maior parte deste período a inflação se manteve próximo das metas propostas, porém devido às altas taxas de juros praticadas, esta política econômica torna mais lenta e penosa a manutenção de níveis de crescimento mais elevados. Conclui-se que devido às consequências que estas políticas têm acarretado para o lado real da economia, tal estratégia de controle de preços carece de uma ampla revisão.
\end{abstract}

Palavras-chave: Regime de Metas de Inflação; Plano Real; Nova Síntese Neoclássica.

Classificação JEL: E31; E43; E52

Towards the twenty years of the inflation targeting regime in Brazil (1999/2016): an analysis of the results

\begin{abstract}
The Inflation Targeting Regime (ITR) is a monetary policy instrument currently used by many countries, both developed and emerging, as an inflation control policy. In July 1999, after several speculative attacks on the Real in the late 1990s, Brazil declined to use the fixed exchange rate as the main tool to control inflation, and adopted the ITR. However, some authors criticize the implementation of this regime in Brazil, and demonstrate that it has not been effective, both in controlling
\end{abstract}

1 Os autores agradecem ao parecerista da revista pelos comentários, críticas e sugestões. Agradecem também às observações do professor Ricardo Ramalhete Moreira (PPGEco-UFES). Quaisquer erros e/ou omissões são de inteira responsabilidade dos autores.

2 Mestrando em Gestão Pública pela Universidade Federal do Espírito Santo. Programa de PósGraduação em Gestão Pública. E-mail: ramony@gmail.com

3 Professor Associado da Universidade Federal do Espírito Santo. Departamento de Economia e Programa de Pós-Graduação em Economia. E-mail: aotsalles@gmail.com 
inflation and in supporting the country's economic growth. Thus, this paper aims to provide arguments to the debate the costs and benefits that the scheme has generated for the Brazilian economy. The main objective is to present the foundations of the regime, make a critical evaluation of its results in Brazil during the period 1999/2014, and analyze the consequences that the ITR maintenance has brought to the Brazilian economy. The analysis reveals that during most of this period inflation remained close to the goals proposed, but due to the high interest rates practiced, this economic policy makes slower and more painful the maintenance of higher growth levels. It is concluded that due to its consequences on the real side of the economy, such a price control strategy needs a broad revision.

Keywords: Inflation Target Regime; Real Plan; New Neoclassical Synthesis.

JEL Classification: E31; E43; E52.

\section{Introdução}

O Regime de Metas de Inflação (doravante RMI) é um instrumento de política monetária utilizado atualmente por diversos países desenvolvidos e emergentes como ferramenta de controle da inflação, tendo sido implantado pela primeira vez na Nova Zelândia em dezembro de 1989. O RMI tem dois objetivos fundamentais: conduzir a inflação para o centro de uma meta previamente estabelecia pela autoridade monetária, e mantê-la neste nível a fim de estabilizar os preços relativos e conquistar a credibilidade dos pricemakers. Após o estabelecimento da meta para o índice de preços (que pode ser anual, como no caso do Brasil, ou plurianual, como por exemplo na Nova Zelândia), a taxa de juros passa a ser a principal ferramenta da autoridade para alcançá-la. Neste contexto, apolítica monetária é executada de forma a sinalizar ao mercado que seu propósito é manter a inflação baixa e estável ao longo do tempo. Assim, o comportamento dos agregados monetários tem um impacto importante sobre as expectativas para a manutenção e estabilidade do regime, de tal forma que a condução da política seja crível pelos agentes.

A partir desta perspectiva, os objetivos deste artigo são: fazer uma revisão dos fundamentos teóricos do RMI; avaliar seus resultados no Brasil no período de 1999 a 2016; e apresentar análises críticas ao regime tal como implementado na economia brasileira no período considerado.

A fim de atingir os objetivos propostos, o artigo foi dividido em cinco seções incluindo esta introdução. A seção dois apresenta as bases teóricas fundamentais do RMI, bem como uma visão panorâmica de suas características nos países que adotaram o regime até o momento. Em seguida, faz-se uma avaliação das características e dos resultados do RMI na economia brasileira (1999/2016). A quarta seção apresenta as críticas teóricas ao funcionamento deste regime no Brasil. Breves considerações finais concluem o artigo. 


\section{Bases teóricas fundamentais e características gerais das experiên- cias históricas do Regime de Metas de Inflação na economia mundial}

Nas duas décadas posteriores à segunda guerra mundial, princípios teóricos definidos como keynesianos foram amplamente utilizados dentro de um arcabouço analítico surgido nos Estados Unidos que ficou conhecido como a Síntese Neoclássica. Segundo os autores que deram origem e desenvolveram os principais argumentos da Síntese (John Hicks, Franco Modigliani, Robert Solow, Paul Samuelson, James Tobin entre outros), a política monetária buscava prioritariamente a sustentação de níveis elevados de emprego. Neste mesmo período, A. W. Philips (1958) verificou a existência de uma relação inversa, estável e não-linear entre a taxa de variação do salário nominal e a taxa de desemprego na economia do Reino Unido no período 1861/1957. As evidências coletadas em seu trabalho empírico mostraram que o baixo nível de emprego poderia explicar a elevação dos salários monetários. A partir do início dos anos 1960, scholars como Samuelson e Solow confirmaram esta relação negativa entre inflação e desemprego utilizando dados da economia americana, batizando assim estetrade-offque propõe mais ou menos inflação ao custo de mais ou menos desemprego como a Curva de Philips.

Uma das consequências deste ambiente intelectual da época foi a modificação na concepção de política econômica - principalmente a monetária - uma vez que estas políticas procuraram se adaptar ao objetivo de "explorar a Curva de Philips" para conduzir a demanda agregada nominal de forma a reduzir o desemprego e alcançar uma taxa de inflação aceitável (Neves e Oreiro, 2008). Porém, no final da década de 1960 e ao longo dos anos 1970, o surgimento de uma situação que combinava inflação e desemprego elevados (estagflação)fez com que a teoria dita keynesiana fosse alvo de duras críticas, fortalecendo a abordagem monetarista. Na esteira deste movimento de reaproximação da macroeconomia com suas bases mais convencionais surge a literatura que lançou os fundamentos do RMI. Mais especificamente, ela se desenvolve ao longo dos anos 1970 e 1980como um dos resultados do debate teórico sobre regra versus discricionariedade na política econômica. Estedebate foi uma peça fundamental do chamado Novo Consenso de Política Monetária, ou a Nova Síntese Neoclássica que não só se tornou uma abordagem teórica dominante na macroeconomia internacional, como também seus princípios têm sido adotados por vários Bancos Centrais ao redor do mundo. ${ }^{4}$

\footnotetext{
Os primeiros fundamentos teóricos que lançaram as bases do RMI foram estabelecidos principalmente por autores como Milton Friedman, Robert Lucas Jr, Finn Kydland e Edward Prescott. Uma extensa literatura sobre o assunto foi produzida após estes autores seminais, grande demais para ser sumariada aqui. Por isso, foge aos objetivos deste artigo apresentar uma lista exaustiva destes autores e recuperar os detalhes da abordagem do regime. Uma visão geral deste assunto pode ser encontrada em Friedman (1956, 1961, 1968 e 1970); Kydland e Prescott (1977); Sevensson (1997a, b); e Clarida, Galí e Gertler (1999). Uma abordagem crítica sobre o sistema de metas pode ser encontrada por exemplo em Heron e Carre (2006), e Lopes, Mollo e Colbano (2012), dentre outros.
} 
Há várias maneiras de apresentar o modelo padrão desta abordagem. Neste artigo, inicia-se pelas equações da curva IS, da curva de Phillips e da regra de Taylor. Através delas, pode-se observar que a taxa natural de juros representa um papel fundamental para a Nova Síntese ou Novo Consenso Macroeconômico. Segundo esta abordagem, quando a taxa nominal de juros de curto prazo encontra-se ao nível da taxa natural de juros, o produto estará em seu nível potencial e a inflação não sofrerá variação. Esta é a situação ideal no modelo. Ademais, a Nova Síntese sugere que um BC responsável deve localizar a taxa natural de juros e persegui-la a todo tempo.

Por este motivo, Arestis \& Sawyer (2008) chegam a afirmar que a visão de economia da Nova Síntese é semelhante à de Wicksell (1898). Isso porque, é a taxa natural de juros que permite um equilíbrio entre oferta agregada e demanda agregada, ou entre poupança e investimento, ao nível de pleno emprego, sem que haja alterações nos preços de mercado. Isso equivale à estabilidade da taxa de inflação $\mathrm{e}$ de uma defasagem de produto nulo nos modelos da Nova Síntese. A economia converge necessariamente para o equilíbrio de pleno emprego (como na Lei de Say), ou seja, para a igualdade entre a taxa de juros de mercado e a taxa natural de juros. Esta seria a única taxa de juros compatível com um equilíbrio econômico.

Formalmente, pode-se apresentar o modelo como se segue. O modelo teórico subjacente ao regime de metas de inflação pode ser descrito através da formalização em Moreira (2011), que parte de uma estrutura novo-keynesiana a fim de realizar uma proposta crítica para aquele regime. O lado da demanda é expresso por uma curva IS dinâmica, tal que:

$$
\text { (1) } \mathrm{y}_{\mathrm{t}}=\mathrm{m}\left(\mathrm{y}_{\mathrm{t}-1}\right)-\mathrm{n}\left(\mathrm{r}_{\mathrm{t}-1}\right)+\eta_{\mathrm{t}}
$$

Onde $y_{t}$ é o hiato do produto em $t$, entendido como a diferença entre o produto efetivo e o produto potencial; $r_{t-1}$ representa a diferença entre a taxa real de juros em t-1 e a taxa real de juros de equilíbrio (i.e. a taxa natural de juros nos modelos novo-keynesianos); e $\eta_{\mathrm{t}}$ é um choque de demanda, com média zero e variância constante. Os parâmetros $m$ e $n$ são positivos. Portanto, o hiato do produto está positivamente correlacionado com seus valores defasados em $\mathrm{t}-1$ e negativamente com o desvio da taxa real de juros em t-1. Por sua vez, o lado da oferta é expresso por uma curva de Phillips:

$$
\text { (2) } \pi_{t}=\tau\left(\pi_{t-1}\right)+\varpi\left(y_{t-1}\right)+g_{t}
$$

Onde $\pi_{\mathrm{t}}$ é o desvio da inflação em $\mathrm{t}$ em relação à meta inflacionária, e $\mathrm{g}_{\mathrm{t}}$ é um choque de oferta, com média zero e variância constante. Os parâmetros $\tau$ e ๒são ambos positivos. Neste sentido, o desvio inflacionário apresenta inércia (que depende de $\tau$ ) e está correlacionado positivamente com o hiato do produto em t-1. Por fim, a regra de política monetária convencional no regime de metas de inflação é dada por uma Regra de Taylor:

$$
\text { (3) } r_{t}=z_{1} \pi_{t}+z_{2} y_{t}+u_{t}
$$


Onde o $\mathrm{BC}$ aumenta a taxa real de juros, em relação à taxa natural de juros, quando $\pi_{\mathrm{t}}>0 \mathrm{e} / \mathrm{ou} \mathrm{y}_{\mathrm{t}}>0$, sendo os parâmetros $\mathrm{z}_{1}$ e $\mathrm{z}_{2}$ ambos maiores que zero. $\mathrm{O}$ termo $u_{t}$ representa um choque de taxa real de juros, com média zero e variância constante. Na prática, os Bancos Centrais ajustam a taxa nominal de juros, porém este ajuste nominal é feito a fim de que a taxa real de juros se comporte de maneira similar à imposta pela equação (3). Pode-se verificar que quando a economia encontra-se em estado estacionário, tem-se que $y_{t}=\pi_{t}=r_{t}=0$. Segundo Moreira (2011), a principal restrição deste tipo de formalização está na exogeneidade do produto potencial, ou seja, o produto potencial é concebido como sendo não-correlacionado com a demanda, ou com a dinâmica do hiato do produto. Isto significa que na estrutura novo-keynesiana a moeda é considerada como neutra no longo prazo, e afeta a dinâmica real da economia apenas no curto prazo.

Philip Arestis e Malcolm Sawyer (2005, p. 7), afirmam que as práticas preconizadas pelo "Novo Consenso Macro econômico" são vistas como "best practices" e que tal Consenso "[...] hasbeenpraisedbymostliterature as a superior framework ofmonetarypolicy. [...] The combination of inflationtargetingandthe NCM wereferto as New Consensus MonetaryPolicy (NCMP) "'.Segundo Benjamim Friedman (1988), a adoção do RMI em diversos países a partir de 1990 (ver quadro 1) sob a égide do NCM foi principalmente motivado pelo fracasso da adoção do regime de metas monetárias na década anterior.

Sob o RMI, a política monetária é executada com o intuito de direcionar a inflação para o centro de uma meta definida previamente. Seu propósito é sinalizar ao mercado que o objetivo da autoridade monetária é manter a inflação estável e baixa no longo prazo. Neste sentido, um dos aspectos fundamentais do regime é a declaraçãoantecipada pela autoridadede uma meta de inflação para um determinado período com o compromisso explícito da autoridade monetária de cumpri-la.Com isso, pretende-se influenciar o processo de decisão de preços dos agentes no sentido de conquistar a aderência dos mesmos trazendo-os para o mesmo patamar em que estão as expectativasdo governo.

Neste sentido, Freitas (2008) propõe que há quatro ferramentas básicas universais subjacentes aoregime: i) o anúncio prévio de uma meta de inflação para um prazo determinado que serve de âncora nominal para coordenação das expectativas dos agentes; ii) o compromisso institucional do Banco Central de buscar a estabilidade dos preços; iii) a transparência na condução da política monetária; e iv) a liberdade institucional da autoridade monetária para a execução dos seus instrumentos disponíveis visando o alcance da meta.

5 Mais especificamente, Arestis e Sayer (2005, p.7)asseveramque o NCM inclui: “(i) the setting by government (normally) of a numerical target range for the rate of (price) inflation; (ii) the use of monetary policy as the key policy instrument to achieve the target, with monetary policy taking the form of interest rate adjustments; (iii) the operation of monetary policy in the hands of an 'independent' central bank; (iv) monetary policy is only concerned with the rate of inflation, and the possible effects of monetary policy on other policy objectives are ignored, or assumed to be non-existent, with the exception of short-term effects." 
Estando estruturado desta forma, o regime se propõe a melhorar a comunicação entre o setor público, os empresários e os mercados em geral “[...] provendo disciplina, responsabilidade, transparência e flexibilidade da política monetária" (Arestis et al., 2009, p. 3). A estabilidade de preços é obtida através de três objetivos: 1)Credibilidade: a organização do regime se propõe a sinalizar confiança aos agentes econômicos através do cumprimento das metas; 2) Flexibilidade: a estrutura operacional deve permitir uma política monetária preventiva de forma a combater e se adaptar a choques não antecipados; e como corolário, 3)Legitimidade: o regime deve contar com suporte dos agentes em geral e das estruturas de poder parlamentar constituídas.

Pode-se concluir, portanto, que no RMI, a política monetária é o principal instrumento a ser utilizado para o controle e manutenção da estabilidade de preços. Por princípio, ela deve ser operacionalizada por um Banco Central (BC) independente ${ }^{6}$. Esta autonomia visa garantir maior credibilidade do BC junto aos mercados, principalmente os mercados financeiros, objetivando catalisar as expectativas destes atores na direção de um ambiente de estabilidade de preços. Isto é obtido através do compromisso de que a manutenção da meta seja alcançada mesmo no longo prazo, evitando que pressões eleitoreiras de curto prazo e descontinuidades das mais diversas ordens (características da alternância de poder) desviem o Banco de seu objetivo.

Segundo as teorias do political business cycles, a classe política tem a tendência de "criar condições econômicas mais favoráveis imediatamente antes das eleições, mesmo que essas políticas venham a exigir ajustamentos de alto custo após as eleições” (FREITAS, 2006, p. 273). Desta forma, os interesses eleitorais podem gerar ciclos econômicos artificiais na condução da política econômica, o que pode conduzir a economia a uma trajetória de aumento contínuo da inflação e a uma variabilidade do produto e do emprego. Uma autoridade monetária subordinada ao Tesouro tem autonomia para adotar políticas monetárias inconsistentes, dando autonomia aos partidos políticos para conduzir a política econômica com fins eleitorais. A independência é considerada pelos teóricos desta corrente como um arranjo institucional capaz de evitar a condução eleitoral da política econômica. Isso reduz ou elimina a interferência de políticos na formulação da política monetária uma vez que os dirigentes do Banco Central estariam desvinculados da conjuntura político-partidária. Tal desvinculação seria uma forma de garantir a harmonização entre os interesses de curto, médio e longo prazo da política econômica e da comunidade.

Para medir o grau de independência do BC considera-se sua competência para formular e executar a política monetária sem intervenção do poder executivo. Assim, cláusulas devem ser incluídas em seu estatuto a fim de garantir determinados aspectos centrais: a) o único objetivo da instituição seja de combater a inflação, impondo limites de interferência do executivo; b) fixação de mandatos que dificultem

A Escola novo-clássica defende que a independência do Banco Central é um mecanismo fundamental para assegurar a estabilidade dos preços. De acordo com esta abordagem, o BC deve ser independente do poder executivo pois, desta forma, pode formular e executar a política monetária de maneira "legítima”, produzindo assim uma política que tenha credibilidade e evitando que o comportamento do governo intervenha na sua condução. 
a demissão de dirigentes por razões políticas, e c) que haja liberdade para definir seu próprio orçamento e a existência de patrimônio próprio (FREITAS, 2006).

A política monetária deve ser feita de forma transparente buscando preservar sua credibilidade e reputação. Assim, a autoridade precisa publicar relatórios periódicos que devem incluir, além da trajetória da inflação, outras variáveis econômicas como produção, emprego, etc, além das condições econômicas do período. No caso de não cumprimento da meta, a autoridade deve publicar relatórios explicando os motivos pelos quais as metas não foram cumpridas. Além disso, informar quais medidas serão implementadas para que o problema não ocorra no futuro. Esta transparência é importante para reduzir as incertezas dos mercados e reduzir as taxas esperadas de inflação.

O RMI precisa ainda prover políticas monetárias que evitem mudanças abruptas na taxa de câmbio. Flutuações excessivas nas taxas de juros, por exemplo, podem causar variações nas taxas de câmbio, e, em consequência, produzir variações significativas no produto. Por conseguinte, o regime propõe que o sistema de taxa de câmbio seja flutuante.

Em linhas gerais, estes são os elementos teóricos fundamentais que dão sustentação ao RMI. Contudo, na prática, o modelo que tem sido implementado varia de país para país de acordo com suas condições econômicas prévias, a cultura local e a concepção dos responsáveis pela implantação do regime. Por exemplo, a meta de inflação a ser estabelecida pode ser pontual ou uma faixa na qual a taxa de inflação a ser perseguida deve estar entre seu limite inferior e superior, além do período de tempo em que deve ser alcançada (vide quadro1 abaixo). A escolha de uma faixa ao invés de um único índice numérico, é mais utilizada porque proporciona maior flexibilidade na estabilidade do sistema para acomodar movimentos na taxa de câmbio nominal (ARESTIS et al., 2009).

O RMI ainda requer um modelo que gere informações sobre a inflação futura, ou seja, uma previsão da inflação. A escolha de um índice de preços de referência pode ser relacionada a um índice global ou um índice de núcleo de inflação. Este último exclui componentes sensíveis aos diversos tipos de choques sobre os quais a margem para adoção políticas monetárias é mais complexa. Desta forma, podem ser excluídos componentes como pagamento de juros de hipoteca, os efeitos dos impostos indiretos, preços regulados, alimentos (que apresentam alta volatilidade), e choques cambiais (NEVES e OREIRO, 2008).

O emprego de cláusulas de escape permite uma maior flexibilidade e até a possibilidade de se desviar temporariamente da meta preestabelecida desde que seja esclarecido ao público o motivo do desvio. Estas cláusulas, que podem ser ou não explícitas, permitem reduzir os custos em termos de emprego e produto, sem comprometer o regime e a credibilidade da autoridade monetária.

O horizonte de tempo a ser utilizado como parâmetro na avaliação do sucesso ou não da condução da política monetária para atingir seu objetivo é de suma importância. Sua extensão dependerá das peculiaridades de cada economia e do objetivo inicial da adoção do regime. Na prática, cada país adota um período de tempo distinto para verificar a eficácia do seu regime. 
Os elementos institucionais do regime variam de acordo com as necessidades do país em questão. Há diferenças no que tange à instância responsável pela definição da meta, ao índice de preços de referência, e ao grau de rigidez ou flexibilidade da estrutura institucional.

$\mathrm{Na}$ maioria dos países, o regime foi introduzido com alterações na legislação, o que confere um caráter permanente ao arcabouço institucional desta estratégia de política monetária. Porém, há exceções como Nova Zelândia e Canadá, onde o RMI faz parte de um compromisso formal entre o poder executivo e o presidente do Banco Central. Este acordo permite o reajuste dos parâmetros acordados (como o índice de referência), o formato da meta, e o horizonte de tempo.

$\mathrm{Na}$ Nova Zelândia, tal compromisso assume a forma de um contrato público denominado Policy Targets Agreement (PTA). Segundo o Banco Central deste país, o contrato em vigor atualmente foi assinado em setembro de 2012 e prevê uma variação anual no Consumers Price Index - CPI, (índice de preços ao consumidor) em um intervalo entre um e três por cento, e $2 \%$ como centro da meta. Freitas (2008) afirma que os contratos anteriores haviam sido assinados em 24 de maio de 2007 e 17 de setembro de 2002. A cada cinco anos em média, um novo contrato é feito.

Em alguns países como Reino Unido e Turquia, a meta é fixada pelo governo. Em outros como Austrália, Canadá, Nova Zelândia e Colômbia, a meta é definida em conjunto do governo com o Banco Central. $\mathrm{Na}$ Coréia, Indonésia, Israel e Tailândia, é fixada pelo governo com consulta ao Banco Central. Há ainda países como Hungria, Polônia, República Tcheca, Suécia e Suíça, em que a responsabilidade de definição da meta é do BC. Outros como Chile e Peru, o BC consulta o governo para esta definição.

Há variações também no que se refere ao índice de preços de referência, ao horizonte temporal para o alcance da meta, e ao formato da meta. Como dito anteriormente, esta pode ser pontual ou com um intervalo inferior e superior, além da possibilidade de adoção de cláusulas de escape da autoridade monetária para o caso de seu não cumprimento.

No quadro abaixo, Hammond (2012) relaciona os 27 países que aderiram ao RMI. A maioria deles (dezessete) começaram a utilizar o regime ao longo dos anos 1990. Pode-se perceber que, em geral, a meta se mostra um pouco inferior nos países que possuem maior histórico de estabilidade econômica. Contudo esta diferença não é tão significativa, indicando que a despeito do histórico ou da "cultura" inflacionária da nação, o propósito do RMI é manter o índice de preços em patamares bastante reduzidos (um dígito). O quadro revela também que a meta de 4,5\% adotada no Brasil' é uma das mais altas, perdendo apenas para Turquia e Gana. Brasil, Turquia e Gana também convergem em outro aspecto: são os únicos países que escolheram adotar uma banda de $+/-2 \%$, a maior do grupo, possivelmente reconhecendo a necessidade de uma maior amplitude para que os instrumentos de po-

Na verdade, segundo a tabela 1 abaixo, a meta de 4,5\% começou a ser adotada a partir de 2005. No primeiro ano de vigência do RMI, a meta era a mesma de Gana (8\%), modificando-se deste ano até 2004. 
lítica monetária de per si acomodem a taxa de inflação. Além disso, observa-se que o país foi o único a adotar o ano-calendário (de $1^{\circ}$ de janeiro a 31 de dezembro), diferente da maioria dos países que adotam uma meta plurianual (ou para "sempre").

\section{Quadro 1: Formatos institucionais do RMI em países selecionados}

\begin{tabular}{|c|c|c|c|c|c|}
\hline Países & $\begin{array}{l}\text { Data da } \\
\text { Adoção }\end{array}$ & $\begin{array}{l}\text { Índice de } \\
\text { Referência }\end{array}$ & $\begin{array}{l}\text { Responsabilidade pela Fixação } \\
\text { da Meta }\end{array}$ & Meta (em 2012) & Horizonte Temporal \\
\hline $\begin{array}{l}\text { África do } \\
\text { Sul }\end{array}$ & Fevereiro/2000 & $\begin{array}{l}\text { IPC (doze } \\
\text { meses) }\end{array}$ & Banco Central & 3 a $6 \%$ & $\begin{array}{c}\text { Base contínua (acumulado } \\
12 \text { meses) }\end{array}$ \\
\hline Armênia & Janeiro/2006 & IPC & $\begin{array}{c}\text { Governo em conjunto com o } \\
\text { Banco Central }\end{array}$ & $\begin{array}{c}4 \%, \text { com intervalo de } \\
\pm 1,5 \%\end{array}$ & 12 meses \\
\hline Austrália & Junho/1993 & IPC & $\begin{array}{c}\text { Governo em conjunto com o } \\
\text { Banco Central }\end{array}$ & Entre 2 a $3 \%$ & $\begin{array}{l}\text { Médio prazo (over the } \\
\text { business cycle) }\end{array}$ \\
\hline Brasil & Junho/1999 & IPC & $\begin{array}{c}\text { CMN, composto pelos ministros } \\
\text { da Fazenda, do Planejamento e } \\
\text { presidente do BC }\end{array}$ & $\begin{array}{l}4,5 \% \text {, com intervalo } \\
\text { de } \pm 2 \%\end{array}$ & Ano calendário \\
\hline Canadá & Fevereiro/1991 & IPC & $\begin{array}{l}\text { Governo em conjunto com o } \\
\text { Banco Central }\end{array}$ & $\begin{array}{l}2 \%, \text { com intervalo } \\
\text { de } \pm 1 \%\end{array}$ & $\begin{array}{l}\text { Acordo com o governo } \\
\text { renovado a cada } 5 \text { anos até } \\
\text { dezembro de } 2016\end{array}$ \\
\hline Chile & Setembro/1999 & IPC & $\begin{array}{l}\text { Banco Central, com consulta ao } \\
\text { governo. }\end{array}$ & $\begin{array}{l}3,0 \%, \text { com intervalo } \\
\text { de } \pm 1 \%\end{array}$ & $\begin{array}{c}\text { Definido mais ou menos a } \\
\text { cada } 2 \text { anos }\end{array}$ \\
\hline Colômbia & Outubro/1999 & IPC & $\begin{array}{l}\text { Conselho de administração (7 } \\
\text { membros) }\end{array}$ & $\begin{array}{c}3,0 \% \text {, com intervalo de } \\
\pm 1 \%(\mathrm{em} 2011)\end{array}$ & $\begin{array}{l}\text { Definido anualmente } \\
\text { por lei }\end{array}$ \\
\hline $\begin{array}{l}\text { Coréia do } \\
\text { Sul }\end{array}$ & Abril/1998 & IPC & $\begin{array}{l}\text { Banco Central com consulta ao } \\
\text { Governo }\end{array}$ & $\begin{array}{l}3,0 \%, \text { com intervalo } \\
\text { de } \pm 1 \%\end{array}$ & 3 anos \\
\hline Filipinas & Janeiro/2002 & $\begin{array}{c}\text { IPC (ás } \\
\text { vezes muda) }\end{array}$ & Conselho Monetário & $\begin{array}{c}4,0 \% \text {, com intervalo } \\
\text { de } \pm 1 \%\end{array}$ & Médio prazo \\
\hline Gana & Maio/2007 & IPC & Governo e Banco Central & $\begin{array}{c}8,0 \% \text {, com intervalo de } \\
\pm 2 \%(\mathrm{em} 2013)\end{array}$ & De 18 a 24 meses \\
\hline Guatemala & 2005 & IPC & Conselho Monetário & $\begin{array}{l}4,0 \% \text { com intervalo de } \\
\pm 1 \%(\mathrm{em} 2013)\end{array}$ & Anual \\
\hline Hungria & Junho/2001 & IPC & Banco Central & $3 \%$ & Médio prazo \\
\hline Indonésia & Julho/2005 & IPC & $\begin{array}{c}\text { Governo, com consulta ao Banco } \\
\text { Central. }\end{array}$ & $\begin{array}{l}4,5 \% \text { com intervalo } \\
\text { de } \pm 1 \%\end{array}$ & Médio prazo \\
\hline Islândia & Março/2001 & $\begin{array}{c}\text { IPC } \\
\text { acumulado } \\
\text { dos últimos } \\
12 \text { meses }\end{array}$ & $\begin{array}{l}\text { Banco Central com aprovação do } \\
\text { primeiro ministro }\end{array}$ & $2,5 \%$ & Média acumulada \\
\hline Israel & Junho/1997 & IPC & $\begin{array}{l}\text { Governo, com consulta ao Banco } \\
\text { Central. }\end{array}$ & 1 a $3 \%$ & Em até dois anos \\
\hline México & 2001 & IPC & Banco Central & $\begin{array}{c}3 \% \text { com intervalo de } \\
\pm 1 \%\end{array}$ & Médio prazo \\
\hline Noruega & Março/2001 & IPC & Governo & Próximo a 2,5\%. & Médio prazo \\
\hline $\begin{array}{c}\text { Nova } \\
\text { Zelândia }\end{array}$ & Dezembro/1989 & IPC & $\begin{array}{c}\text { Governo e o Ministro das } \\
\text { Finanças } \\
\end{array}$ & Entre 1 a 3\% & Médio Prazo \\
\hline Peru & Janeiro/2002 & IPC & $\begin{array}{c}\text { Conselho de administração } \\
\text { (incluído o Governo) }\end{array}$ & $\begin{array}{c}2 \% \text { com intervalo de } \\
\pm 1 \%\end{array}$ & Sempre \\
\hline Polônia & 1998 & IPC & Conselho de Política Monetária & $\begin{array}{l}2,5 \% \text { com intervalo } \\
\text { de } \pm 1 \%\end{array}$ & Médio Prazo \\
\hline $\begin{array}{l}\text { Reino } \\
\text { Unido }\end{array}$ & Outubro/1992 & $\begin{array}{l}\mathrm{IPC}(12 \\
\text { meses })\end{array}$ & Governo & $2 \%$ & Sempre \\
\hline $\begin{array}{l}\text { República } \\
\text { Checa }\end{array}$ & Dezembro/1997 & IPC & Banco Central & $\begin{array}{c}2 \% \text {, com intervalo } \\
\text { de } \pm 1 \%\end{array}$ & $\begin{array}{c}\text { Médio Prazo (de } 12 \text { a } 18 \\
\text { meses) }\end{array}$ \\
\hline Romênia & Agosto/2005 & IPC & Banco Central e Governo & $\begin{array}{l}2,5 \% \text { com intervalo } \\
\text { de } \pm 1 \%\end{array}$ & Meta plurianual \\
\hline Sérvia & Janeiro/2009 & IPC & $\begin{array}{l}\text { Banco Central em colaboração } \\
\text { com o governo }\end{array}$ & $\begin{array}{c}4 \%, \text { com intervalo de } \\
\pm 1,5 \%\end{array}$ & Médio Prazo \\
\hline Suécia & 1995 & IPC & Banco Central & $2 \%$ & Dois anos (pode variar) \\
\hline Tailândia & Maio/2000 & IPC & Comitê de Política Monetária & $\begin{array}{c}3 \%, \text { com intervalo de } \\
\pm 1,5 \%\end{array}$ & Prazo Indefinido \\
\hline Turquia & Janeiro/2006 & IPC anual & $\begin{array}{c}\text { Governo e o Comitê de Política } \\
\text { Monetária }\end{array}$ & $\begin{array}{l}5 \%, \text { com intervalo } \\
\text { de } \pm 2 \%\end{array}$ & 3 anos \\
\hline
\end{tabular}

Fonte: Adaptado a partir de Hammond(2012). 
Ainda de acordo com o quadro 1, em todos os cinco continentes do mundo existe algum país que aderiu ao regime. O Brasil foi o décimo segundo a adotá-lo, o primeiro da América Latina e o segundo de todo continente americano. O quadro também registra que a adesão ao regime não foi idêntica em todos os países. As razões para isso são complexas, mas há que se ressaltar as inúmeras diferenças quanto à estrutura econômica, política e social de cada um. Tais diferenças podem ser muito significativas, principalmente quando se coloca nações desenvolvidas e subdesenvolvidas lado a lado. Uma vez que se considera que a operacionalização da política econômica depende de elementos cruciais que extrapolam aspectos econômicos, isso significa que o mesmo pacote de medidas pode gerar incongruências importantes de país a país. Três indicadores do quadro acima (responsabilidade institucional pela fixação da meta, percentual estabelecido para a meta e horizonte temporal) revelam que a adoção do regime passou por adaptações idiossincráticas nos diferentes países. Por isso, a seção seguinte se ocupa de fazer uma análise da operacionalização do regime no Brasil e dos resultados obtidos no período 1999/2016.

Há muitas formas de fazer este tipo de análise da economia brasileira. O que se segue, está focado em examinar os resultados do regime a partir da observação do comportamento da taxa de juros, tão cara à permanência do RMI, e da taxa de câmbio uma vez que reflete as condições macroeconômicas externas que tem importantes repercussões sobre o sistema de preços doméstico.

\section{A implantação do RMI no Brasil e os resultados observados}

Tendo sido implementadoem primeiro de julho de 1994,o Plano Real apresentou um bom desempenho no seu papel de controlar a inflação até 1998, porém problemas fiscais aumentaram excessivamente o déficit público. Além disso, neste ano, a apreciação do Real em relação às principais moedas internacionais trouxe grandes desequilíbrios no balanço de pagamentos do país. Em função dos déficits em conta corrente (que atingiu mais de 4\% do PIB em 1998), e com a alta taxa de juros no período, o país passou a conviver com situações de fragilidade externa, o que causava recorrentes ataques especulativos ao Real ao longo deste período (ARESTIS et al., 2009).

Além da gravidade dos problemas fiscais, a crise financeira asiática do segundo semestre de 1997 gerou forte desvalorização de várias moedas destes países. A instabilidaderelacionada ao nível de solvência internacional dos países emergentes atingiu as reservas internacionais do Brasil. Durante a crise, as reservas do país não conseguiram evitar um forte ataque especulativo ao Real, o que provocou um aumento da vulnerabilidade externa da economia. Como consequência, ocorreuuma redução tanto no ingresso de capitais de curto pra- 
zo quanto das reservas cambiaisno início de 1998.Em setembro e outubro deste ano, a crise da Rússia era o principal foco de instabilidade do mercado financeiro internacional, que defato que contagiou a economia brasileira, provocando em setembro de 1998 um novo ataque especulativoao Real (LOPES e MOURA, 2001).

O governo decidiu manter a política cambial principalmente porque 1998 era um ano de eleições presidenciais. A equipe econômica do então presidente Fernando Henrique Cardoso, que almejava reeleição,insistia no conservadorismo fiscal e monetário, anunciando um novo pacote fiscal e uma elevação da taxa básica de juros que foi de $29,7 \%$ a.a. em junho para $42,2 \%$ a.a. em dezembro deste mesmo ano. Desta vez, porém, a elevação da taxa de juros não foi suficiente para estimular a entrada de capital estrangeiro de forma a estabilizar as reservas cambiais, como era feito anteriormente neste mesmo governo para evitar uma crise cambial. Por isso, as reservas foram reduzidas drasticamente. Entre junho e dezembro de 1998, caíram paracerca de $38 \%$. Na tentativa de solucionar o problema, foi feito um acordo com o Fundo Monetário Internacional (FMI) em dezembro de 1998no qual a economia brasileira recebeu US $\$ 40$ bilhões em aporte de recursos emergenciais, comprometendo-se a cumprir algumas metas de austeridade fiscal e monetária em um contexto de liberalização cambial, financeira e comercial(FERRARI-FILHO, 2001).

Em função deste acordo e diante da fragilidade financeira externa do país e da impossibilidade de reverter o grau de vulnerabilidade com medidas monetária e fiscal convencionais, o governo foi forçado a desvalorizar o câmbio. Com consequência desta conjunção de fatores desestabilizadores no contexto internacional, a âncora cambial - principal instrumento do Plano Real para o controle da inflação - foi eliminada em janeiro de 1999. Em suma, após vários ataques especulativos ao Real no final dos anos 1990, o Brasil deixa de usar a âncora cambial como principal ferramenta para controle da inflação e passa a adotar o RMI em julho de 1999. Desde então, uma série de questões tem surgido em relação à eficácia deste regime e a seus impactos na economia brasileira.

A alteração no câmbio causou de imediato um surto inflacionário. A taxa de câmbio saltou de R \$1,20/US\$1,00 em janeiro de 1999 para R \$ 2,10/US\$ 1,00 em março. A inflação medida pelo IGP-DI da Fundação Getúlio Vargas que foi de 1,7\% durante em 1998para 19,9\% em 1999. Esta grande desvalorização cambial forçou o governo a abandonar o acordo com o FMI (FERRARI-FILHO, 2001) e acúmulo de problemas na operacionalização da política monetária do país levou à saída de Gustavo Franco da presidência do BC no início de março de 1999, sendo substituído por Armínio Fraga Neto, à época membro da diretoria da Soros Fund Management.

Fraga Neto assume a presidência do Banco numa situação macroeconômica de alta instabilidade uma vez que a super desvalorização da moeda nacional 
implicou no fim da âncora-cambial,um dos pilares fundamentais do Plano Real. Por conta disto, o mercado começa a formar expectativas pessimistas acerca do comportamento futuro dos preços. Diante da possibilidade de ocorrer uma explosão inflacionária, as autoridades monetárias decidiram pela implementaçãodo RMI no Brasil com o objetivo de manter a inflação sob controle.

Em 2011, o BC publica um extenso relatório para comemorar dez anos de implantação do RMI no país (1999-2009). Nele, Fraga descreve a conjuntura macroeconômica do período de alta inflação dos anos 1980 e início dos 1990 que precedeu a adoção do Plano Real. Ele mencionou queembora o governo FHC tenha anunciadoum importante ajuste fiscal antes das eleições presidenciais de 1998, não foipossível resistir à pressão sobre a taxa de câmbio, provocando a livre flutuação do Real, com consequências imprevisíveis para a estabilidade da moeda.

Foi nesse contexto que surgiu a ideia de se adotar um sistema de metas para a inflação, seguindo o exemplo de países como o Reino Unido, a Suécia e a Nova Zelândia. A adoção do sistema foi fruto de um processo de exclusão de alternativas tais como: a volta ao câmbio fixo ou administrado (que nunca durou muito); a criação de uma caixa de conversão como a da Argentina (um rígido currency board); a introdução de metas monetárias (notoriamente instáveis); ou a simples condução da política monetária sem meta explícita para a inflação. A opção pelo sistema de metas para a inflação em momento de crise e incerteza refletiu uma enorme preocupação com o risco de perda de controle sobre as expectativas de inflação. Num país com nossa história de inflação, tal descontrole traria consigo a ameaça da reindexação e o pesadelo do retorno à instabilidade que existia antes do Plano Real. A explicitação de metas nos pareceu um bom caminho para comprometer as ações de governo com seus objetivos de médio e longo prazo e, em caso de sucesso, começar a acumular um precioso capital de credibilidade (FRAGA, 2011, p. 26).

Ainda de acordo com Fraga (2011), a introdução do sistema foi feita de modo gradual no início de 1999 a fim de evitar um choque de expectativa. Foi anunciado que o BC almejava uma taxa anualizada de um dígito no último trimestre do ano. Para sinalizar este compromisso, a taxa de juros foi elevada de $39 \%$ para $45 \%$ a.a. Assim, apesar do discurso gradualista do presidente do banco, esta significativa elevação nos juros refletia, por um lado, a grande preocupação da autoridade com compromisso de trazer os preços para o centro da meta de inflação. Por outro, criou um ambiente pouco favorável aos investimentos, representando assim, em suas próprias palavras, "uma medida bastante antipática”. Foi anunciado também a introdução de um viés de baixa nesta taxa, o que permitiria sua redução entre reuniões do Comitê de Política Monetária (COPOM) sem a convocação de uma reunião extraordinária. 


\subsection{O formato Brasileiro do RMI e seu desempenho de 1999 a 2016}

O RMI foi formalmente implantado no país em $1^{\circ}$ de julho de 1999 através do decreto presidencial no 3.088 e da resolução no 2.615 do Conselho Monetário Nacional (CMN). O CMN escolheu o Índice de Preços ao Consumidor Amplo (IPCA) da Fundação Instituto Brasileiro de Geografia e Estatística (IBGE) como índice para determinação e funcionamento do regime. De acordo com o decreto, a responsabilidade de definição da meta para a taxa de juros da economia (SELIC) é do Banco Central, e a magnitude da taxa é definida pelo COPOM.

O Decreto estabelece a obrigatoriedade do BC divulgar relatórios trimestrais de inflação com informações macroeconômicas e justificativas para as medidas adotadas. O banco deveria também publicar as atas de decisões do COPOM relativas à definição da taxa SELIC e seu viés de alta, baixa ou neutro. Caso a meta não seja atingida, o presidente do BC é obrigado a enviar uma carta aberta ao Ministro da Fazenda justificando as razões do não cumprimento e definindo medidas de correção para que a inflação retorne ao patamar esperado. Oficialmente, o não cumprimento da meta pode acarretar até a demissão do presidente e da diretoria do $\mathrm{BC}$.

A tabela 1 abaixo apresenta um histórico do RMI no Brasil (e alguns agregados macroeconômicos importantes para sua avaliação) desde sua implantação até o último fechamento do ano calendário na dataem que o presente artigo foi publicado. Isso significa que existem dados consolidados referentes ao período de 1999 a 2016, portanto, o regime encontra-se rumo a vinte anos de vigência no país. Neste período de quase duas décadas, ocorreram mudanças radicais no cenário macroeconômico do país e do mundo, boa parte delas com algum tipo de impacto na determinação do sistema de preços doméstico. Nestes anos ocorreram desde crises monetárias, bancárias e financeiras localizadas em diferentes partes do mundo,uma crise energética do Brasilem 2001 ("crise do apagão"), o atentado terrorista de 11 de setembro de 2001, a crise Argentina e a crise de confiança causada meses antes das eleições presidenciais de 2002, até a mais grave crise financeira global desde 1929. Logo, pode-se supor o potencial de inconsistências sobre o processo de formação de preços disseminado através de efeitos sobre contas públicas, política econômica, salários nominais,etc como efeitos destas crises. Por isso, esta seção não tem o objetivo de sumariar todas estas repercussões. Dados os objetivos deste artigo, a análise a seguir está focada em captar o comportamento da variável fundamental definida pelo RMI para o controle de preços e os resultados por ela auferidos no IPCA. 
Tabela 1: Resultados obtidos pelo RMI no Brasil (1999/2016) e alguns agregados macroeconômicos relacionados

\begin{tabular}{|c|c|c|c|c|c|c|c|c|c|c|c|}
\hline \multirow[b]{2}{*}{ Ano } & \multicolumn{5}{|c|}{ IPCA (\%) } & \multirow{2}{*}{$\begin{array}{c}\text { Resultados } \\
\text { obtidos }\end{array}$} & \multirow{2}{*}{$\begin{array}{c}\text { Taxa Selic } \\
\text { acumulada } \\
\text { em } 12 \\
\text { meses } \\
(\%)\end{array}$} & \multirow{2}{*}{$\begin{array}{l}\text { PIB } \\
(\%)\end{array}$} & \multicolumn{3}{|c|}{$\begin{array}{c}\text { Taxa de Câmbio } \\
\text { BRL/USD }\end{array}$} \\
\hline & Meta & $\begin{array}{l}\text { Meta } \\
\text { ajustada }\end{array}$ & Banda & $\begin{array}{l}\text { Limites } \\
\text { inferior e } \\
\text { superior }\end{array}$ & $\begin{array}{l}\text { Inflação } \\
\text { efetiva }\end{array}$ & & & & Jan & Jun & Dez \\
\hline 1999 & 8 & - & 2 & $6,0-10,0$ & 8,94 & $\begin{array}{c}\text { Cumpriu no } \\
\text { limite superior } \\
\text { da banda }\end{array}$ & 24,76 & 0,47 & 1,5 & 1,77 & 1,84 \\
\hline 2000 & 6 & - & 2 & $4,0-8,0$ & 5,97 & $\begin{array}{c}\text { Cumpriu } \\
\text { no centro da } \\
\text { meta }\end{array}$ & 17,60 & 4,11 & 1,8 & 1,81 & 1,96 \\
\hline 2001 & 4 & - & 2 & $2,0-6,0$ & 7,67 & Descumpriu & 17,46 & 1,66 & 1,95 & 2,38 & 2,36 \\
\hline 2002 & 3,5 & - & 2 & $1,5-5,5$ & 12,53 & Descumpriu & 19,22 & 3,05 & 2,38 & 2,71 & 3,63 \\
\hline 2003 & 3,25 & 4,0 & 2,5 & $1,5-6,5$ & 9,3 & Descumpriu & 23,51 & 1,14 & 3,44 & 2,88 & 2,93 \\
\hline 2004 & 3,75 & 5,5 & 2,5 & $3,0-8,0$ & 7,6 & $\begin{array}{l}\text { Cumpriu no } \\
\text { limite superior } \\
\text { da banda }\end{array}$ & 16,38 & 5,76 & 2,85 & 3,13 & 2,72 \\
\hline 2005 & 4,5 & - & 2,5 & $2,0-7,0$ & 5,69 & $\begin{array}{l}\text { Cumpriu no } \\
\text { limite superior } \\
\text { da banda }\end{array}$ & 19,14 & 3,20 & 2,69 & 2,41 & 2,29 \\
\hline 2006 & 4,5 & - & 2 & $2,5-6,5$ & 3,14 & $\begin{array}{c}\text { Cumpriu abai- } \\
\text { xo da meta }\end{array}$ & 15,32 & 3,96 & 2,27 & 2,25 & 2,15 \\
\hline 2007 & 4,5 & - & 2 & $2,5-6,5$ & 4,46 & $\begin{array}{c}\text { Cumpriu } \\
\text { no centro da } \\
\text { meta }\end{array}$ & 12,04 & 6,07 & 2,14 & 1,93 & 1,79 \\
\hline 2008 & 4,5 & - & 2 & $2,5-6,5$ & 5,9 & $\begin{array}{c}\text { Cumpriu no } \\
\text { limite superior } \\
\text { da banda }\end{array}$ & 12,45 & 5,09 & 1,77 & 1,62 & 2,39 \\
\hline 2009 & 4,5 & - & 2 & $2,5-6,5$ & 4,31 & $\begin{array}{l}\text { Cumpriu abai- } \\
\text { xo da meta }\end{array}$ & 10,13 & $-0,13$ & 2,31 & 1,96 & 1,75 \\
\hline 2010 & 4,5 & - & 2 & $2,5-6,5$ & 5,91 & $\begin{array}{l}\text { Cumpriu no } \\
\text { limite superior } \\
\text { da banda }\end{array}$ & 9,90 & 7,53 & 1,78 & 1,81 & 1,69 \\
\hline 2011 & 4,5 & - & 2 & $2,5-6,5$ & 6,5 & $\begin{array}{l}\text { Cumpriu no } \\
\text { limite superior } \\
\text { da banda }\end{array}$ & 11,76 & 4,00 & 1,67 & 1,59 & 1,84 \\
\hline 2012 & 4,5 & - & 2 & $2,5-6,5$ & 5,84 & $\begin{array}{c}\text { Cumpriu no } \\
\text { limite superior } \\
\text { da banda }\end{array}$ & 8,63 & 1,92 & 1,79 & 2,05 & 2,08 \\
\hline 2013 & 4,5 & - & 2 & $2,5-6,5$ & 5,91 & $\begin{array}{l}\text { Cumpriu no } \\
\text { limite superior } \\
\text { da banda }\end{array}$ & 8,29 & 3,02 & 2,03 & 2,17 & 2,35 \\
\hline 2014 & 4,5 & - & 2 & $2,5-6,5$ & 6,41 & $\begin{array}{c}\text { Cumpriu no } \\
\text { limite superior } \\
\text { da banda }\end{array}$ & 10,96 & 0,50 & 2,38 & 2,24 & 2,66 \\
\hline 2015 & 4,5 & - & 2 & $2,5-6,5$ & 10,67 & Descumpriu & 13,47 & $-3,85$ & 2,66 & 3,18 & 3,91 \\
\hline 2016 & 4,5 & - & 2 & $2,5-6,5$ & 6,29 & $\begin{array}{l}\text { Cumpriu no } \\
\text { limite superior } \\
\text { da banda }\end{array}$ & 14,18 & $-3,59$ & 4,05 & 3,62 & 3,26 \\
\hline 2017 & 4,5 & - & 1,5 & $3,0-6,0$ & & & & & & & \\
\hline 2018 & 4,5 & - & 1,5 & $3,0-6,0$ & & & & & & & \\
\hline
\end{tabular}

Fonte: Banco Central do Brasil e IBGE. Elaboração própria. 
Nesta lógica, a exposição que se segue divide este período de dezoito anos em três momentos distintos de acordo com o tempo de permanência no cargo de presidente do BC. Assim, o primeiro período em análise será da presidência de Armínio Fraga Neto (1999/2002). Em seguida, será estudado os anos de 2003 a 2010, período em que Henrique de Campos Meirelles (2003 a 2010) foi o presidente do banco. E finalmente, os anos de 2011 a 2016 em que Alexandre AntonioTombini ocupou o cargo. ${ }^{8}$

\subsubsection{Os primeiros anos de implantação do RMI (1999-2002)}

Em janeiro de 1999 o Presidente Fernando Henrique Cardoso toma posse em seu segundo mandato em meio a uma forte desvalorização do real após a mudança do regime de câmbio fixo para câmbio flutuanteenquanto instrumento de política econômica.Além disso, o governo substituiu também da Taxa de Assistência do Banco Central (TBAN)', que, juntamente com a Taxa Básica do Banco Central (TBC), estabelecia o custo dos empréstimos de liquidez concedidos aos bancos no sistema de redesconto. Este ano também foi marcado por uma elevada intensidade dos ajustes na política de juros, mesmo antes da implementação do RMI no mês de junho. Em abril, a taxa Selic anualizada era de $45 \%$ eo Copom decide por uma queda de $11 \mathrm{pp}$. No mês seguinte, novamente se utiliza um viés de baixa e a taxa é reduzida em 10,5 pp. O regime é inaugurado na reunião do Copom do dia 23 de junho. Portanto, inicia com um nível de taxa Selic de $23,5 \%$ aa e com um viés de queda. A partir de junho, os ajustes se tornam menos intensos. Até a última reunião do ano ocorrem quatro decisões de manutenção e apenas duas pequenas reduções (em julho de 1,5 pp e setembro de 0,5 pp). Assim, a Selic inicia $1999 \mathrm{em} 29 \%$ aa, atinge seu ponto maiselevado em abril aos $45 \%$ aa,e encerra o ano em $19 \%$ aa (em termos nominais), demonstrando assim uma elevada volatilidade. Por sua vez, a taxa de inflação fecha o ano em $8,94 \%$ portanto próximo do limite superior mas dentro da banda estabelecida pelo CMN. Vale lembrar, um pouco abaixo da média dos quatro anos do primeiro mandato do presidente Fernando Henrique Cardoso, que foi de 9,3\%. ${ }^{10}$

No ano de 2000 prevaleceu a tendência de queda dos juros, partindo de $19 \%$ aa chegando em dezembro a 16,5\%aa. Desta vez, o IPCA atingiu o centro da meta. No ano seguinte, em função deste excelente resultado obtido, o Copom decidiu fazer poucas intervenções na Selic de tal forma que a taxa encerrou 2001 nos mesmos $19 \%$

8 Precisamente, Fraga Neto ocupou a presidência do BC durante o período de 04/03/1999 a 01/01/2003. Meirelles ficou mais tempo no cargo. Seu intervalo foi de 01/01/2003 a 01/01/2011, enquanto que Tombini presidiu o banco de 01/01/2011 a 08/06/2016.

9 A TBAN foi criada pela Circular do BC no 2.711 de 28 de agosto de 1996 durante a gestão de Gustavo Loyola. A forma como isso era feito foi estabelecida pela Resolução ${ }^{\circ} 2.308$ do banco assinada no mesmo dia (BANCO CENTRAL DO BRASIL, 1996a e 1996b).

10 Nos anos de 1995, 1996, 1997 e 1998 os índices atingiram, respectivamente, 22,41\%; 9,56\%; 5,22\% e $1,6 \%$. 
de 1999. Contudo, a inflação deste ano superou em mais de um ponto percentual o limite superior da banca que era de 6\%. Em 2002 a Selic atinge os $21 \%$. Este ano foi marcado por elevada instabilidade macroeconômica no paísque gerou umaforte depreciação do Real devido aos problemas de natureza política provocados pelas eleições presidenciais de outubro.Um sinal desta instabilidade foi que neste mesmo mês, o Copom se reuniu extraordinariamente e decidiu por unanimidade pela elevação da taxa em $3 \mathrm{pp}$. Como consequência, neste ano a depreciação cambial teve um rápido repasse para o IPCA, o que contribuiu ainda mais para a elevação da inflação. De fato, a taxa alcançada neste ano não apenas foi mais que o dobro do limite superior da banda mastambém representou a maior extrapolação que o país registrou durante o regime de metas até 2016.

No front internacional, um dos principais desafios enfrentados pelo governo no período 1999-2002 foram os desequilíbrios externos, que levaram o país a enfrentar a crise cambial que já se desenhava no final de 1998, mas que se aprofundou no ano seguinte. $\mathrm{Na}$ crise, os investidores internacionais passaram a questionar a capacidade de pagamento dos países em desenvolvimentodada a necessidade de financiamento destes para fechar o balanço de pagamentos. A partir daí, começou uma intensa fuga de capitais do país, na qual a política de desvalorizações graduais do real via bandas cambiais não se mostrou eficiente para fazer a reversão dos fluxos de capitais.

Foi exatamente por conta deste contexto de incertezas políticas e econômicasque o $\mathrm{BC}$ abandonou o sistema de âncora cambial e adotou o regime de câmbio flutuante. A reação foi um overshooting, com uma desvalorização imediata do câmbio nominal da ordem de $70 \%$ nos primeiros meses. Com a mudança do regime cambial e a aderência ao RMI como regra para a política monetária, o banco procurou também implementar medidas de austeridade fiscal a fim de alcançar metas de superávit primário. Desta forma, a política econômica estava fundamentada no tripé macroeconômico câmbio flutuante, regime de metas de inflação e metas de superávit primário.Contudo, o resultado destes anos em que Fraga Neto presidiu o $\mathrm{BC}$ foram dúbios. Como mostra da tabela 1, as metas foram cumpridas em $1999 \mathrm{e}$ 2000 e descumpridas em 2001 e 2002 apesar da taxa Selic se manter em um patamar muito elevado. Por sua vez, as taxas de crescimento do PIB se mantiveram positivas em todos os anos mas não demonstraram uma tendência consistente de alta.

\subsubsection{A estruturação do regime (2003-2010)}

Em janeiro de 2003, Luiz Ignácio Lula da Silva assume o governo e dá posse a Henrique Meirelles como novo presidente do BC. O contexto era deelevada instabilidade e de expectativas negativas sobre a condução da política macroeconômica em função do debate acirrado sobre o tema durante o período da campanha eleito$\mathrm{ral}^{11}$.Nestas circunstâncias, a nova equipe assume o Copom com o desafio de trazer

11 Meirelles ficou no cargo até o fim do segundo mandato de Lula em dezembro de 2010. 
a inflação de volta ao patamar de um dígito obtido desde 1996, e ao mesmo tempo reverter o pessimismo do setor privado quanto à condução macroeconômica do novo governo. Uma vez que o IPCA do ano anterior havia fechado num nível bem acima da meta, e em função do ambiente macroeconômico desfavorável, o CMN decidiu reajustar a metade inflação com base nas projeções e cenários futuros desenhados pela nova equipe econômica. Neste sentido, ela foi revisada para cima, de $3,25 \%$ para $4 \%$ em 2003 , e de $3,75 \%$ para $5,5 \%$ em 2004 .

Neste conturbado ano de 2003, a taxa de câmbio teve uma pequena apreciação que foi de $R$ \$ 3,44 por dólar em janeiro, para $R$ \$2,88 em junho, fechando o ano em $\mathrm{R} \$ 2,93$. Essa relativa estabilidade do câmbio auxiliou o Copom na retomada da confiança dos agentes e definição de uma nova trajetória para a Selic e da inflação. Após as duas primeiras reuniões, a tendência da Selic ao longo do ano foi de queda acentuada. A taxa iniciou 2003 num patamar de $25 \%$ aa (em termos nominais) e encerrou em $17,5 \%$ aa. Deve-se lembrar que este foi o primeiro ano de um partido que defendeu com veemência a geração de empregos através de várias medidas de política econômica, em particular com o apoio de uma redução da taxa de juros. Isso foi feito gradualmente em 2003, contudoo índice de inflação superou pelo terceiro ano consecutivo o teto da meta, fechando em 9,3\%. Até 2016, esta situação de descumprimento da meta por três anos seguidos também foi uma situação inédita. Desde este ano, a inflação só voltou a extrapolar a meta em 2015, outro ano bastante conturbado uma vez que do ponto de vista econômico o país passava por uma grave crise fiscal, e do ponto de vista político, por uma severa crise de confiança por conta de inúmeros problemas de natureza institucional, denúncias de corrupção e do acolhimento do processo de impeachment contra a presidente Dilma Rousseff.

Do ponto de vista global, esta fase é denominada na literatura internacional como a "Grande Moderação", ou seja, é um período marcado pelo novo ciclo de liquidez internacional associado com forte expansão do comércio mundial, que propiciou condições favoráveis para o ingresso de capitais estrangeiros no Brasil. ${ }^{12}$ Dada a "Grande Moderação", este desempenho está relacionado ao forte crescimento da economia mundial e seu impacto sobre o preço das commodities agropecuários e metálicas, produtos preponderantes na pauta comercial brasileira, que ampliaram os ganhos do país em suas vendas externas.

As exportações apresentaram um crescimento acumulado de quase 100\% entre 2003 e 2006 enquanto que as importações tiveram um crescimento menos acelerado. A apreciação cambial de 2003 em diante não impactou o saldo comercial, resultado claro do período de bonança externa que o país vivia. Contudo, nestes quatro anos, o Brasil apresentou déficits na balança de serviços e rendas, decorrente do aumento das despesas com viagens internacionais e aluguéis de equipamentos,

12 A este respeito, veja o discurso feito à EasternEconomicAssociationpor Ben Bernanke (2004). Analisando o período de estabilidade econômica da economia dos Estados Unidos desde o início de 1985 até o final de 2007, ele argumenta que a política monetária tinha se tornado tão eficiente e confiável que era capaz de eliminar a volatilidade da economia. 
beneficiados pela apreciação cambial. Além disso, houve forte remessa de lucros e dividendos ao exterior. Por fim, a conta capital e financeira não sofreu um impacto imediato das condições de liquidez favorável para os países emergentes já que em 2003 e 2004, a entrada líquida de capitais foi pequena ou negativa.

Em 2005, esses fluxos já haviam apresentado resultado positivo, ancorado não somente no ingresso de investimentos diretos, mas também nos investimentos de portfólio. A quitação do empréstimo com o FMI, contraído entre 1998 a 2003, foi responsável por parte expressiva do déficit em conta financeira entre 2005 e 2006. Em 2006, a conta financeira volta a apresentar superávit graças ao saldo positivo da rubrica de investimento em carteira e outros investimentos, decorrente do aumento dos empréstimos de longo prazo.

A redução da fragilidade externa brasileira no período favoreceu a redução contínua da taxa de juros, embora ela permanecesse em um patamar elevado para os padrões internacionais (tabela 1). O diferencial de juros entre as taxas interna e externa combinado com a redução do risco-país contribuiu para a atração de investidores estrangeiros e maiores pressões para a valorização cambial. Para evitar movimentos bruscos na taxa de câmbio, o BC realizou constantes intervenções resultantes na política de acumular reservas internacionais, a partir de 2004. A aquisição de recursos no mercado de câmbio elevou as referidas reservas para um nível recorde que, combinado com a queda a dívida externa, tornou o Brasil credor líquido em moeda estrangeira desde então e reduziu sua vulnerabilidade externa. Neste período, o BC adotou três medidas: redução da taxa de juros a partir de meados de 2003; reversão deste movimento de queda com aperto da política monetária em função de pressões inflacionárias do $4^{\circ}$ trimestre de 2004 ao $3^{\circ}$ trimestre de 2005; e retomada do processo de expansão monetária no $4^{\circ}$ trimestre de 2005 . Após o triênio 2001/2003 desastroso, o país tem um triênio seguinte muito melhor em termos de eficiência do RMI uma vez que em 2004 e 2005 a inflação ficou dentro dos limites da banda, e em 2006 registrou 3,14\%, portanto, abaixo da meta de 4,5\%.

De 2007 ao terceiro trimestre de 2008, o país passa por um momento de prosperidade do comércio mundial e grande liquidez internacional. Tais fatores, somados às persistentes taxas de juros reais elevadas no Brasil, médias de 7,1\% a.a em 2007 e 6,2\% em 2008, provocaram o ingresso de capitais de curto prazo no Brasil, excessiva apreciação cambial e retomada da deterioração nas contas correntes, muito embora a balança comercial tenha permanecido superavitária ao longo destes anos. Contudo, é neste momento que se instala a crise financeira de 2008. Em 2007 a inflação ficou no centro da meta de $4,5 \%$ e em 2008 , no limite superior da banda $(5,9 \%)$.

A partir de 2008, percebe-se um cenário internacional instável, com ciclos de expansão e contenção de liquidez que se alternam em curto prazo. Ao mesmo tempo, há desaquecimento da demanda internacional, inclusive dos países em desenvolvimento. No Brasil, políticas econômicas anticíclicas foram adotadas e permitiram que o país não sofresse abalos muito intensos da crise internacional, à exceção de 
2009, quando a economia decresceu 0,6\%. Porém, já em 2010 o PIB cresceu 7,53\%, mostrando o sucesso das políticas anticíclicas.

O foco dos policymakers em 2010 voltou-se para a política cambial e para inibir a entrada massiva de capitais especulativos no país. O principal instrumento para conter a apreciação do real frente ao dólar e restringir a entrada de capitais de curto prazo no país foi a elevação do Imposto sobre Operações Financeiras (IOF) que, coibiu o influxo de recursos responsáveis pela apreciação cambial. Do ponto de vista externo, observa-se expressiva melhora nos indicadores de endividamento em relação ao ano anterior por conta da elevação do estoque de reservas internacionais, o que reduz a dívida externa líquida. Adicionalmente, o crescimento das exportações em $32 \%$ provocou a queda dos dois indicadores de dívida externa e dívida externa líquida que se relacionam com esta variável.

\subsubsection{Tensões econômicas e políticas: o RMI no limite superior da banda (2011 a 2016)}

Especialmente a partir de 2011, a crise da dívida soberana na zona do Euro fez com que as economias periféricas solicitassem ajuda financeira de emergência. Em um cenário de desconfiança dos investidores internacionais e retração do crescimento global, o governo brasileiro implementou uma sequência de políticas econômicas visando a redução da inflação e a aceleração da economia nacional. Dentre as medidas adotadas, destaca-se: busca de meta de superávit fiscal ajustada ao ciclo; política monetária mais discricionária e com conjunto maior de instrumentos, como as macroprudenciais; ampliação do controle de capitais mediante a cobrança do IOF nas operações com derivativos cambiais e uma alíquota maior para aquisição de empréstimos estrangeiros com prazo de até um ano. Esta objetivava conter a apreciação cambial e diminuir a entrada de capital de curto prazo; e lançamento de nova política industrial para promover o investimentos em inovação, pesquisa e desenvolvimento em setores estratégicos (CUNHA e FERRARI FILHO, 2012).

Tais ações geraram uma combinação entre a política monetária, cambial e fiscal na contenção da inflação. A interação delas, associada à percepção do desaquecimento da economia doméstica possibilitou uma redução gradual na taxa de juros a partir de agosto de 2011, levando a Selic a fechar o ano em 11,76\% a.a. No âmbito externo, a consistência da política econômica brasileira associado à solidez das contas externas acarretou em elevação nas notas de crédito soberano do Brasil pelas principais agências de classificação de risco. Mesmo com o menor ritmo da atividade econômica global e aumento da aversão ao risco dos investidores internacionais, o Brasil conseguiu manter uma posição externa fortalecida.

$\mathrm{O}$ ano de 2012 iniciou com grande instabilidade mundial devido à deterioração da situação financeira na Zona do Euro, redução nível da atividade econômica mundial, do comércio internacional, volatilidade dos fluxos internacionais de capitais, e desconfianças sobre os preços das commodities (BIANCARELI, 2012). 
Contudo, Biancarelli (2012) afirma ainda que o influxo de investimento direto em patamares elevados, mesmo em uma conjuntura econômica mundial desfavorável, foi uma resposta às políticas econômicas adotadas no país, que conferiu confiança dos investidores estrangeiros às perspectivas de expansão econômica.

Nesta conjuntura, 2012 foi marcado por reduções significativas na taxa básica de juros que fez a Selic alcançarem outubro 7,5\% a.a., o segundo menor patamar até 2016, o que conteve a tendência de apreciação cambial apresentada em 2011. A redução da fragilidade externa é compreendida pela diminuição do estoque da dívida externa de curto prazo, redução do estoque de portfólio devido a expressiva saída de capital estrangeiro em ações de companhia brasileiras, associados ao forte ingresso de investimento direto. Isso foi suficiente para cobrir o déficit nas transações correntes, e a redução do déficit de serviços, sendo que estes dois últimos fatores compensaram a queda do superávit do saldo comercial.

A tendência da taxa Selic ao longo de 2013 foi de elevação, após atingir o seu menor nível histórico: 7,25\%aa. A política monetária começou o ano, na primeira reunião $\left(172^{a}\right)$, mantendo o nível da meta para a taxa Selic, mas a partir de abril/2013, o Copom iniciou uma contração monetária por meio da elevação de 0,25pp inicialmente para sinalizar a reversão na política de juros que estava começando. Nas quatro reuniões seguintes, a meta para a taxa Selic foi elevada 0,5\%aa, sucessivamente, em cada reunião. O resultado, na última reunião do ano (25/nov/2013) foi uma taxa básica de 9,5\%aa, sem o uso de viés. É importante observar que o Copom teve um ano de decisões quase consensuais (do início ao fim), à exceção da terceira, quando decidiram pela manutenção da Selic. Portanto, o ano termina com a Selic ainda em seu nível mais baixo de 7,25aa e a inflação abaixo da meta, em 5,91\%.

Do ponto de vista externo, a trajetória dos anos de 2013 e 2014 repete o processo observado desde 2011, de valorização cambial, oscilação dos fluxos internacionais de capital, desconfiança dos investidores internacionais, volatilidade das moedas dos países emergentes.Entretanto, 2014 foi um ano muito conturbado do ponto de vista político por conta de dois fatores essenciais: as investigações da Operação Lava Jato em março que investigava um esquema de lavagem de dinheiro que movimentou bilhões de reais em propina pagos principalmente por empreiteiras a uma importante empresa pública, a Petrobrás. Nesta, estão envolvidos funcionários de alto escalãodesta empresa estatal, além de políticos dos maiores partidos do Brasil, presidentes da República, presidentes da Câmara dos Deputados e do Senado Federal, governadores de estados, e empresários de grandes empresas brasileiras. Este também foi um ano de eleições gerais no Brasil (presidente da república, governadores, senadores e deputados federais). As denúncias da Lava Jato sobre o uso dos recursos públicos foram a base para o questionamento da gestão macroeconômica e, principalmente, fiscal do governo de Dilma Rousseff.A presidente é eleita no final do ano em um cenário de grande instabilidade política e econômica.

Em 2015, a crise política provocada pelo avanço das investigações sobre corrupção agravaram sobremodo o cenário econômico do país, principalmente do pon- 
to de vista da condução da política fiscal. Apesar do aumento da taxa de juros de 10,96\% em 2014 para 13,47\% (valores acumulados), a inflação volta pela primeira vez desde 2003 a superar a meta, e a fechar acima de dois dígitos, o que não acontecia desde 2002. Em termos do PIB, a economia retrocedeu e quase $4 \%$, o que significou o pior resultado dos últimos 25 anos segundo o IBGE. Este péssimo resultado, juntamente com juros elevados, implicou em queda da arrecadação, numa crise nas contas dos estados, redução do volume de financiamento, aumento do desemprego e queda na confiança dos investidores.

Em outubro deste ano, o Tribunal de Contas da União (TCU) abriu uma investigação após denúncia do Ministério Público Federal junto ao tribunal para investigar as chamadas "pedaladas fiscais"13 cometidas pela presidente naquele ano. No mês de dezembro, ocorre o acolhimento pelo então presidente da Câmara do Deputados, Eduardo Cunha, do pedido de impeachment da presidente Dilma Rousseff ${ }^{14}$, fato que iria repercutir gravemente na condução da política econômica do ano seguinte.

2016 foi um ano de tantos acontecimentos marcantes na economia brasileira que seria necessário o espaço de um artigo (ou mais de um) para analisar detidamente todos eles. Em 2016 a inflação volta a ficar dentro da meta mas a opinião especializada concorda em admitir que a recessão econômica, o aumento do desemprego e a elevada taxa de juros foram os principais elementos responsáveis por este desempenho. Pelo segundo ano seguido, o Brasil registrou contração na economia, desta vez de $-3,59 \%$. Do ponto de vista político, o país passou por momentos graves. Em agosto, a presidente foi afastada do cargo devido à aprovação no Congresso Nacional do processo de impeachment. Isso gerou uma temerosa crise deconfiança no país que certamente afetou a economia como um todo até o fim deste ano.

Chega-se então ao último ano em análise neste artigo em um cenário de recessão, de precariedade de expectativas e de elevada incerteza. A experiência da política monetária num ambiente incerto tem catalisado a atenção de inúmeros pesquisadores, bem como a formulação do conhecimento que embasa as decisões da autoridade monetária (a dimensão epistêmica da incerteza) desperta interesse na pesquisa sobre política monetária (DEQUECH, 2000, 2001). Certamente o país precisará de agora em diante de mais pesquisas nesta área para fundamentar os próximos passos de política econômica a ser adotada pelos próximos governos, se se pretende que o regime dure por mais tempo de forma bem sucedida. A instalação

13 O termo conhecido como "pedaladas fiscais" é na verdade um crime contra a Lei de Responsabilidade Fiscal (Lei Complementar 101, de 4 de maio de 2000), que regulamenta todas as movimentações de finanças feitas por entidades federais, estaduais e municipais. Esta Lei estabelece normas de finanças públicas voltadas para a responsabilidade na gestão fiscal (chamada de "Lei de Responsabilidade Fiscal"). Nos termos da Lei, as "pedaladas" são operações orçamentárias realizadas pelo Tesouro Nacional não autorizadas pela legislação, que consistem em atrasar o repasse de verba a bancos públicos e privados com a intenção de aliviar momentaneamente a situação fiscal do governo. .

14 As "pedaladas" foram uma das fundamentações técnicas do pedido de impeachment aceito por Eduardo Cunha e assinado pelos juristas Hélio Bicudo, Miguel Reale Júnior e Janaína Paschoal. 
do RMI no Brasil se deu num ambiente de incerteza fundamental e forte (DEQUE$\mathrm{CH}, 1999 \mathrm{a}, 2000$ ) o que dificulta a manutenção da meta de inflação sem a necessidade de um período de recessão para manter os preços represados. Conforme pôde ser observado na discussão acima, nestes dezoito anos, o país tem convivido com períodos de quebras estruturais, rupturas institucionais e crises internas mas também que extrapolam as fronteiras do país. Por isso, acredita-se que chegou o momento de repensar esta trajetória e os rumos da política econômica.

Conforme estabelecido de início, o objetivo desta seção foi fazer um exame dos resultados do RMI no período de 1999 a 2016 focado no estudo do comportamento da taxa de juros e da taxa de câmbio. $\mathrm{Na}$ esteira desta análise, foi inevitável tangenciar algumas questões de natureza política dada a influência que tiveram sobre a tomada de decisões dos policymakers no Brasil, principalmente em $2015 \mathrm{e}$ 2016. A seção seguinte se propõe a fazer uma avaliação mais crítica deste sistema de estabilização de preços.

\subsection{Uma análise críticaao modelo Brasileiro de RMI}

Apesar do RMI emergir como uma proposta teórica de controle inflacionário a partir do Novo Consenso Macroeconômico, isso não significa que haja unanimidade, nem ao menos uma grande concordância sobre a eficácia deste modelo enquanto estratégia de política monetária adequada para países desenvolvidos e emergentes. Em particular, autores da Escola Pós-keynesiana têm elaborado uma série de críticas ao formato e aos resultados obtidos pelo regime.

De uma forma geral, a crítica Pós-keynesiana afirma que o RMI não prevê que o produto potencial também pode cair ao longo do tempo, ou crescer menos que o produto efetivo quando a taxa de juros sobe. Para estes autores, a moeda não é neutra no curto e no longo prazos. Isso significa que, assim como as outras mercadorias do sistema econômico, ela possui uma demanda própria devido às suas propriedades de inelasticidade de produção e substituição, sendo assim considerada um "poço sem fundo de liquidez" na linguagem da Teoria Geral de Keynes. Esta não neutralidade fica muito evidente quando se leva em conta que, sob incerteza, os agentes podem desviar a sua demanda por bens de capital para aumentar sua preferência pela liquidez, provocando impactos na economia tão mais relevantes quanto maior for o grau de pessimismo diante da incalculabilidade dos eventos. Logo, o grau de preferência pela liquidez desta moeda não neutra tem grande importância para a realização dos investimentos. Por conseguinte, a liquidez do sistema bancário é o que garante ao investidor condições de empréstimos apropriadas para o investimento..$^{15}$

15 A este respeito, Lopes, Mollo e Colbano (2012, p. 288) asseveram que: "Só, portanto, condições monetárias favoráveis, em termos de reduzida preferência pela liquidez dos bancos e dos poupadores, garantem o crescimento do investimento e então da produção, da capacidade de produção e do emprego na economia. [...] [sendo assim, o Regime de Metas de Inflação] ao aumentar os juros, reduz tanto o produto efetivo como o produto potencial, ameaçando a produção, a capacidade produtiva e o emprego.” 
De forma esquemática, Drumond e Porcile (2013) sintetizam a crítica pós-keynesianapontuando quatro problemas estruturais do regime:

1) Os modelos convencionais do RMI consideram a taxa natural de crescimento do produto determinado unicamente pelo lado da oferta. Contudo, autores pós-keynesianos acreditam que a situação da economia no longo prazo é influenciada pelos eventos que ocorrem no curto prazo, o que é conhecido como path-dependence. Assim, não faz sentido pensar em um "produto natural" a ser perseguido pelo Banco Central;

2) O RMI considera a neutralidade da moeda, especialmente no longo prazo, uma vez que considera a ideia de "taxa natural de crescimento do produto". Como mencionado acima, a abordagem pós-keynesiana entende (como Keynes) que a moeda é não neutra no curto e no longo prazo;

3) O RMI considera a inflação oriunda unicamente de fatores ligados à demanda. No pensamento pós-keynesiano,as causas da inflação surgem do conflito distributivo característico das economias capitalistas, onde os preços são fixados, de um lado, pela margem de lucro desejada e, do outro, pelo salário almejado pelos trabalhadores;

4) Para o Novo Consenso a taxa natural de juros deve ser considera na formulação da função de reação da política monetária. Todavia, a interpretação pós-keynesiana entende que a taxa de juros é um fenômeno monetário. Por isso, não faz sentido falar em taxa natural de crescimento, nem sequer em uma taxa natural de juros.

De acordo com Terra (2014), sob o RMI, a autoridade monetária pode ser capturada pelo sistema financeiro (leia-se, pelos bancos comerciais) devido ao fato destes possuírem a capacidade de criar moeda. Isso porque os pressupostos do regimepropõem que a causa da inflação está no viés-inflacionário da autoridade monetária. Desta forma, a inflação percebida pelo RMI é tipicamente de demanda. Isso significa que a autoridade monetária operacionaliza a taxa básica de juros a fim de desviar a demanda presente para o futuro, acomodando-a dessa formapara dentro dos limites colocados pela oferta agregada.

Como mencionado acima, sob a ótica pós-keynesiana, bancos são instituições que buscam o lucro monetário atuando em um ambiente de incerteza, portanto suas decisões de investimento levam em consideração as expectativas em relação ao futuro. Por sua vez, o modelo convencional do RMI estabelece que os Bancos Centrais informemàs instituições bancárias dados tais como: a meta de inflação, o tempo proposto para seu alcance, os objetivos da política monetária, etc. Terra (2014) contra-argumenta que, se o objetivo da autoridade monetária é controlar a demanda agregada, é o sistema bancário que define qual será o preço pelo qual este controle será exercido já que este possui o poder de definir a magnitude da demanda agregada através de sua habilidade a criar moeda de crédito. Desta forma, quanto mais os bancos reduzirem seu grau de preferência pela liquidez, mais intensa terá 
que ser a atuação da autoridade monetária para controlar a demanda agregada. Em suma, a crítica de Terra (2014, p. 117) pode ser assim enunciada:

sob o RMI quanto mais os bancos reduzirem suas preferências pela liquidez, mais intensa terá de ser a reação da $\mathrm{AM}$, o que significa que maiores terão de ser os juros que ela deverá estabelecer para controlar a concessão de crédito. O resultado lógico, portanto, é que sob o RMI, a AM torna-se capturada pelos bancos, que se utilizam da constrição de ação do Banco Central como meio para reduzir suas incertezas sobre quais decisões tomar a bem da obtenção de maiores lucros.

Strachman (2013) afirma que na aplicação do RMI por meio da definição das taxas de juros, o BC do Brasil não considerou adequadamente as conseqüências sobre o emprego e o crescimento econômico no longo e no curto prazo, dando preferência a ganhos menos importantes com a taxa de inflação exclusivamente. Para ele, o BC também não mensurou devidamente os efeitos fiscais no aumento da taxa de juros, tais como: o crescimento do volume das despesas financeiras do setor público; o aumento da dívida, que ocorre ao mesmo tempo em que háqueda relativa da receita tributária do país; aumentos nos gastos sociais e com desemprego; a desaceleração do crescimento econômico médio, e elevação da relação dívida/produto, com riscos de dominância fiscal, situação em que oEstado perde a capacidade de gerar receita suficiente para financiar seus gastos.

Além disso, o autor critica ainda o câmbio flutuante adotado no regime. Ele destaca que uma depreciação da moeda pode causar fortes impactos nos "preços, como resultado da transferência (pass-through) dos preços das importações de insumos e bens finais, assim como de uma maior demanda por - e de maiores preços em moeda nacional das - exportações" (STRACHMAN, 2013, p. 426). As empresas nacionais ainda podem ser impactadas com depreciações cambiais repentinas por conta de dividas e pagamentos programados em moedas estrangeiras, uma vez que suas receitas são recebidas em moeda nacional.

O autor destaca que de 1999 até 2012, quando o RMI alcançou resultados dentro da meta por 12 anos, e não atingiu a meta em apenas dois, o país teve o menor crescimento econômico da AméricaLatina e dos BRICs por vários anos. Em suas palavras, neste período ocorreu um

comprometimento acentuado do crescimento econômico e industrial em todos esses anos, vale dizer, de forma alguma as expectativas foram estabilizadas "naturalmente" em direção a níveis baixos de inflação, incentivando, posteriormente - como muitos apontam que, segundo a teoria, deveria ter ocorrido - uma ampliação dos investimentos e do crescimento econômico (STRACHMAN, 2013, p. 427).

Para Strachman (2013) em seus 14 primeiros anos no Brasil o RMI conseguiu manter, no geral, baixas taxas de inflação, no entanto, à custa de reduzidas taxas de crescimento no curto prazo, com repercussões negativas sobre o crescimento no longo prazo. As expectativas do mercado em relação à elevação das taxas de juros 
e sufocamento de qualquer ritmo mais vigoroso da atividade econômica causam baixas taxas de investimento e crescimento, permanentes.

Por sua vez, Lobo e Oreiro (2014) afirmam que a operacionalização do RMI tem efeitos diretos no crescimento econômico dos países que o adotam. Eles analisam os efeitos da regra de determinação da taxa de juros de curto prazo adotada pelo BC sobre o crescimento econômico por meio de um modelo de crescimento pós-keynesiano baseado em Taylor e O’Connell (1985).Afirmam que é possível estabelecer uma relação não linear entre a taxa de juros de longo prazo e o grau de utilização da capacidade produtiva, onde existiriam dois pontos de equilíbrio no curto prazo capaz de permitir um maior crescimento econômico por meio da condução da política fiscal por parte do governo.

O modelo parte de duas premissas básicas: considera a existência de três classes sociais na economia, os capitalistas, os trabalhadores e os rentistas; a taxa de juros de curto prazo é uma função crescente da taxa de inflação, enquanto que a taxa de juros de longo prazo é determinada no mercado de empréstimo bancários. No caso de variações exógenas na inflação, um aumento taxa de juros de curto prazo da economia, levará a um aumento da taxa de juros de longo prazo, fazendo com que a economia convirja para um novo ponto de equilíbrio, onde a taxa de juros de longo prazo é maior, e a taxa de lucro, menor. Isso acarreta em um elevado sacrifício em termos de crescimento do produto por conta do aumento da taxa de juros de curto prazo pelo BC.

Lobo e Oreiro (2014, p. 153) chegam à conclusão de que quanto maior a disposição do Banco Central em "elevar a taxa de juros de curto prazo em face de desvios da inflação em relação à sua meta e do produto em relação ao seu potencial, menor será a probabilidade de essa economia se encontrar em um ponto de equilíbrio de longo prazo estável.” Portanto, para que a economia trilhe uma trajetória de crescimento de longo prazo, é necessário que o $\mathrm{BC}$ tenha um comportamento cauteloso na variação da taxa de juros.

Para Nassif (2015), partindo de uma análise de médio ou de longo prazo, o tripé da política macroeconômica brasileira, que combina o RMI a um regime de câmbio flutuante e metas de superávit fiscal primário, não tem sido capaz de garantir nem a estabilidade dos preços e nem o crescimento econômico. Para o autor, há um relativo consenso de que a dívida pública dos países em desenvolvimento deve ser, preferencialmente, financiada por meio de emissão de títulos e bônus, e não de emissão monetária. Além disso, o estoque da dívida pública não pode crescer indefinidamente. Há um nível determinado deste estoque em relação ao PIB. Casoeste seja ultrapassado, pode aumentar a desconfiança do mercado em relação à capacidade de solvência da dívida por parte do tesouro. Desta forma, o regime força o governo a adotar uma política fiscal com superávits primários, até conseguir reduzir a dívida a níveis baixos e estáveis. O problema é determinar qual é este nível da dívida.

De acordo com o autor, a equação do modelo convencional do RMI que define a expansão da dívida ao longo do tempo,que considera os gastos totais do setor 
público, os impostos arrecadados e a taxa de juros real incidente sobre o estoque da dívida, negligencia aspectos importantes sobre o gerenciamento da dívida em países emergentes. Em particular, a maturidade de vencimento e os critérios para remuneração dos títulos. No caso do Brasil, ele destaca o fato de que a maior parte dos títulos públicos emitidos, as LFTs, é vinculada à taxa básica de juros e afirma que esta vinculação tem um efeito duplo negativo. Isso porque

primeiro, reduz a potência da política monetária quando o Banco Central aumenta a taxa de juros para reduzir a inflação; e, segundo, ao aumentar a taxa de juros, os detentores da dívida contam com um enorme incentivo para aumentar sua posição em carteira na forma desses títulos públicos, uma vez que seu custo de oportunidade e risco é reduzidíssimo, posto que são rolados diariamente no overnight (NASSIF, 2015, p. 429).

Outra crítica em relação a função da taxa de juros no RMI parte da premissa de que apesar do BC brasileiro modificar a SELIC para controlar a demanda agregada, o papel da taxa de juros brasileira tem sido de controlar a entrada de capitais, por meio de uma taxa de cambio relativamente apreciada(MANDARINO; MOREIRA, 2013).

A política monetária pode afetar a inflação de duas maneiras por meio de uma redução monetária. Diminuindo o produto e a inflação através da curva de Phillips, e também por meio da valorização cambial causada pela contração monetária, o que também reduz a inflação de forma direta. Os autores ainda destacam que o núcleo da inflação no Brasil não é proveniente de choques de demanda e sim de choques de oferta. Os autores apontam evidências de que a inflação brasileira medida pelo IPCA, tem sido determinada majoritariamente pela "dinâmica dos preços de commodities, ao passo que a proxy de gap do produto utilizada no estudo não mostrou-se estatisticamente significante como causa antecedente da inflação ao consumidor, para a economia brasileira recente” (MANDARINO; MOREIRA, 2013, p. 119).

$\mathrm{O}$ aspecto inercial da inflação brasileira pode ser atribuído a indexação dos preços administrados. Na maioria das vezes, estes preços são controlados por contratos baseados nas variações anteriores de preços, que são geralmente reajustados pelo IGP (índice geral de preços), que é mais sensível a variações cambiais do que o IPCA, utilizado no RMI. Desta forma, observa-se maiores taxas de inflação em períodos em que o câmbio permanece desvalorizado.

Os autores destacam, que o controle da inflação no Brasil é alcançado, de certa forma, por meio da apreciação cambial, e que a política monetária deveria também ter como objetivo alcançar uma taxa de câmbio mais competitiva. Apesar de ter alguma influência sobre os preços livres da economia, a política monetária tem pouca capacidade de alterar os preços administrados. Assim, a formulação da política monetária no Brasil deveria levar em consideração os preços estabelecidos em contrato (MANDARINO; MOREIRA, 2013).

Mandarino e Moreira (2013) afirmam também que o BC deixa em segundo planos outras variáveis afetadas pela taxa de juros na condução do RMI, como o montante de juros pago com a rolagem da dívida pública e o tamanho do déficit pú- 
blico. A preocupação majoritária da autoridade monetária é a estabilização dos preços e por isso não é dada muita importância para a magnitude da taxa de juros, o que faz com que a economia brasileira entre em uma "armadilha da taxa de juros/taxa de câmbio", onde uma redução na taxa de juros no Brasil causa uma depreciação do real, o que eleva a inflação, antes mesmo da redução da taxa de juros ter causado qualquer efeito na demanda. Esta armadilha "é um dos indícios de que o controle da inflação no país passa necessariamente pela taxa de câmbio" (MANDARINO; MOREIRA, 2013, p. 121). Este controle se demonstra perverso, uma vez que a adoção de uma taxa de cambio apreciada para fazer frente a inflação faz com que, mais cedo ou mais tarde, o país passe a enfrentar um desequilíbrio em suas contas. Para a correção, o país passaria por uma crise ou quase-crise, depreciação cambial e por consequência, aumento da inflação.

\section{Considerações finais}

Até o momento, arelativa estabilidade de preços é sem dúvida o maior legado do Plano Real, porém há muitos avanços a serem perseguidos pela economia brasileira no que se refere à manutenção da estabilidade macroeconômica de longo prazo. A este respeito, um dos pontos mais críticos é sem dúvida a taxa de juros que se mantém entre as mais altas do mundo. Além disso, o crescimento do PIB, que, como foi mostrado na tabela acima, cresce a um ritmo dezig-zag e é inferior ao de nações com características econômicas semelhantes. E finalmente, a má distribuição de renda que torna o país uma referência negativa em termos de desigualdade social e desenvolvimento econômico e humano.

Desde a implantação do Plano Real, a economia brasileira depende fortemente do capital estrangeiro para controlar a inflação. Desta forma, o país se vê obrigado a manter um grande volume de reservas internacionais a um custo financeiro elevado. Estasreservas não seriam em si um problema, porém há que se levar em contao custo de oportunidade que têmpara o ajuste das contas públicas do país. $\mathrm{Ou}$ seja, o governo paga uma alta taxa de juros para a rolagem da dívida pública e recebe uma taxa baixíssima nas reservas aplicadas no exterior, o que implica em um enorme dispêndio de recursos públicos com pagamentos de juros.

Além disso, as altas taxas de juros contribuem para a limitação do investimento no país. Como consequência, promovem uma elevação interna de preços por conta da limitação que esta pode causar no lado da oferta. Por fim, contribuem para o aumento do spread bancário, encarecendo também empréstimos e financiamentos para o consumidor final.

Esta política monetária restritiva exigida para a manutenção do RMI, tem por objetivo manter a variação do nível de preços em um patamar estável e sob controle. Apesar disto, a análise da literatura especializada conclui que este regime não é o principal responsável pela estabilidade de preços em vários países semelhantes ao Brasil. Ademais, em função das altas taxas de juros praticadas, a política econômica 
do RMI torna mais lenta e penosa a manutenção de níveis de crescimento mais elevados no país, e portanto da melhoria do padrão de vida da população.

Desta forma, destaca-se a necessidade de implantação de uma nova estrutura de política fiscal e monetária. Esta nova estrutura deve visar não só o controle da inflação, mas principalmente incentivar o crescimento econômico através do aumento do investimento público e privado, e da consequente elevação do nível agregado de emprego e de bem-estar da sociedade.

\section{Referências bibliográficas}

ARESTIS, P; SAYWER, M.New Consensus Monetary Policy: an appraisal. In: ARESTIS, P; BADDELEY,M; MCCOMBIE, J. (Orgs.).The New Monetary Policy: Implications and Relevance. Londres: Edward Elgar, 2005.

ARESTIS, Philip; PAULA, Luiz Fernando; FERRARI-FILHO, Fernando.2009.A nova política monetária: uma análise do regime de metas de inflação no Brasil.Economia e Sociedade, v. 18, n. 1, pp. 1-30.

BANCO CENTRAL DO BRASIL.Circular $n^{\circ}$ 2711. Brasília, 28 de agosto de 1996a.

BANCO CENTRAL DO BRASIL.Resolução $n^{\circ}$ 2.308. Brasília, 28 de agosto de 1996b.

BANCO CENTRAL DO BRASIL. Dez anos de metas para a inflação no Brasil 1999 - 2009, Brasília: Banco Central do Brasil, 2011.

BERNANKE, Ben. The Great Moderation.Remarks by Governor Ben Bernanke at the Meetingsof the Eastern Economic Association, 2004.

BIANCARELI, A. M. Uma nova realidade do setorexternobrasileiro, emmeio à criseinternacional. Textoparadiscussão no. 13.Campinas: Rede Desenvolvimentista, 2012, 49 p.

CLARIDA, R., GALÍ, J, \& GERTLER, M. The scienceofmonetarypolicy: a new Keynesian perspective". 1999. Journal of EconomicLiterature, v. XXXVII, pp. 16611707, December.

CUNHA, A.; FERRARI FILHO, F. Será que as políticas econômicas implementadas no Brasil em resposta a crise financeira internacional podem ser consideradas keynesianas?. In: MODENESI, A.; et al (Org). Sistema financeiro e política econômica em uma era de instabilidade: tendências e perspectivas para a economia brasileira. Rio de Janeiro: Elsevier, 2012. p. 145-152. 
CURADO, Marcelo; OREIRO, José L. 2005. Metas de inflação: uma avaliação do caso Brasileiro. Indic. Econ. FEE, Porto Alegre, v. 33, n. 2.

DEQUECH, D. Expectations and confidence under uncertainty. Journal of Post Keynesian Economics, p. 415-430, 1999a.

DEQUECH, David. Incerteza num sentido forte: Significado e Fontes. In: LIMA, G.; SICSÚ, J; PAULA, L. F. (org). Macroeconomia Moderna: Keynes e a economia Contemporânea. Rio de Janeiro: Campus, 1999b.

DEQUECH, D. Fundamental uncertainty and ambiguity. Eastern Economic Journal.p.41-60, 2000.

DEQUECH, D. Bounded rationality, institutions, and uncertainty. Journal of Economic Issues, p. 911-929, 2001.

DRUMOND, Carlos Eduardo; PORCILE, Gabriel. Um modelo dinâmico de macroeconomia aberta com metas de inflação, conflito distributivo e equilíbrio na conta corrente. Economia e Sociedade, Campinas, v. 22, n. 3 (49), p. 675-695, dez. 2013.

FERRARI FILHO, Fernando.2001.O legado do Plano Real: Uma estabilização sem crescimento econômico. Revista Análise Econômica. Ed. 35.

FERRARI FILHO, Fernando; SCHIFINO Lucas Aronne.2010.Performance macroeconômica sob o regime de metas de inflação:uma análise para alguns países emergentes selecionados.III Encontro da Associação Keynesiana Brasileira.

FRAGA, Armínio 2011. Dez Anos de Metas para a Inflação. In: BANCO CENTRAL DO BRASIL. Dez anos de Metas para a Inflação - 1999-2009. Brasília: Banco Central do Brasil, 2011.

FREITAS, Maria Cristina P. Banco Central Independente e coordenação das políticas macroeconômicas: lições para o Brasil. Economia e Sociedade, Campinas, v. 15, n. 2 (27), 2006.FREITAS, Maria Cristina P. Regime de metas de inflação em perspectiva comparada.Fundap Grupo de Conjuntura, 2008.

FRIEDMAN, Benjamin1988. Monetary Policy without quantity variables.NBER Working Paper. n. 2552, Cambridge.

FRIEDMAN, Milton. "The Quantity Theory of Money - A Restatement.Studies in the Quantity Theory of Money, ed. Milton Friedman.1956.Chicago:UniversityofChicago Press,pp. 3-21. 
FRIEDMAN, Milton. The Lag In Effect of Monetary Policy. Journal of Political Economy.1961. Vol. 69, n. 5, pp. 447-466, Oct..

FRIEDMAN, Milton. [1962].Capitalismo e liberdade. São Paulo: Nova Cultural, 2. ed. 1985

FRIEDMAN, Milton. The Role of Monetary Policy.The American Economic Review, 1968.Vol. 58, n. 1, p. 1-17, March.

FRIEDMAN, Milton. A Theoretical Framework for Monetary Analysis.1970. Journal of Political Economy, v. 78, n. 2, p. 193-238, March-April.

HAMMOND, Gill.State of the art of inflation targeting.Centre for Central Banking Studies. Handbook no. 29, 2012.

HERON, E. Le; CARRE, E. Credibility versus Confidence in Monetary Policy. 2006.In: WRAY, R. L. e FORSTATER M. Money, Financial Instability and Stabilization Policy, Cheltenham/UK: Edward Elgar, p. 58-84.

IBGE - INSTITUTO BRASILEIRO DE GEOGRAFIA E ESTATÍSTICA. Sistema Nacional de Índice de Preços ao Consumidor. Rio de Janeiro, 2005.

KYDLAND, F; PRESCOTT, E. Rules Rather than Discretion: The Inconsistency of Optimal Plans. 1977. JournalofPoliticalEconomy, v. 85, n. 3, p. 473-492, June.

LOBO, Breno Santana; OREIRO, José Luis. Metas de inflação, crescimento e estabilidade macroeconômica: uma análise a partir de um modelo pós-keynesianomacrodinâmico não linear. Revista Economia e Sociedade, Campinas, v. 23 n. 1 (50), p. 131-154, 2014.

LOPES, Carlos Magno e MOURA, João Gonsalo. 2001.Ataques especulativos no Brasil: 1994-1999. In: Anais do XXIX Encontro Nacional de Economia, Salvador/BA.

LOPES, Herton Castiglioni.2011.A inflação e os Planos Cruzado e Real: Uma análise institucionalista. Porto Alegre, RS. Tese (Doutorado em Economia com ênfase em Economia do Desenvolvimento) - Programa de Pós-Graduação em Economia, Faculdade de Ciências Econômicas, Universidade Federal do Rio Grande do Sul, Porto Alegre. 253 p.

LOPES, Mariana de L. M.; MOLLO, Maria de L.Rollemberg; COLBANO, Fabiano S. 2012. Metas de inflação, regra de Taylor e neutralidade da moeda:uma crítica pós-keynesiana. Revista de Economia Política, v.32 no.2. 
MANDARINO, Gabriel Vieira; MOREIRA, Ricardo Ramalhete. O regime de metas de inflação e a taxa de juros como ferramenta da política monetária. OIKOS, Rio de Janeiro. v. 12, n. 1, 2013. p. 112-132.

MENDONÇA, Helder Ferreira. 2004. Mensurando a credibilidade do Regime de Metas de Inflação no Brasil. Revista de Economia Política, vol. 24, nº 3.

MISSIO, Fabrício; ALVES, Fabiano D.; FRAINER, Daniel; CORONEL, Daniel A. 2006. Metas de inflação e o modelo estrutural de previsão: uma análise a partir do caso Brasileiro. Revista Teoria e Evidência Econômica, Revista v.n.27.

MODENESI, André de Melo; ARAÚJO, Eliane Cristina. 2010. Determinantes Macroeconômicos da Inflação: implicações para a política monetária, Dossiê da Crise II, AKB - Associação Keynesiana Brasileira.

MODENESI, André de Melo. 2008. Efeito convenção e inércia na taxa SELIC: uma estimativa da função de reação do BCB (2000-2007), I Encontro Internacional da Associação Keynesiana Brasileira.

MOREIRA, Ricardo Ramalhete. 2011. Flexibility in an Inflation Targeting Regime under Demand Shocks: a Model with Endogenous Potential Output from the Demand Side. JournalofEuropeanEconomy, v. 10, p. 306-326.

NASSIF, André. As armadilhas do tripé da política macroeconômica brasileira. Revista de Economia Política.Vol. 35, nº 3 (140), pp 426-443, 2015.

NEVES, André Lúcio; OREIRO, José Luís. 2008. O regime de metas de inflação:uma abordagem teórica. Ensaior FEE, v. 29, n. 1.

PASTORE, C. A. PINOTTI, M. C; ALMEIDA, L. P. 2004.Public debt, exchange rate shocks and inflation targets.Seminário 5 anos de Metas de Inflação - Banco Central do Brasil.

PHILLIPS, A. W. 1958. The Relationship between Unemployment and the Rate of Change of Money Wages in the United Kingdom 1861-1957. Economica, v. 25, n. 100, pp. 283-99.

SICSÚ, João. Expectativas inflacionárias no regime de metas de inflação: uma análise preliminar do caso brasileiro.Revista de Economia Política, São Paulo, v. 22, n. 1 (85), p. 23-33, 2002a.

SICSÚ, João. 2002b. Teoria e Evidências do Regime de Metas Inflacionárias. Revista de Economia Politica. v. 22, n. 1. 
STRACHMAN, Eduardo. Metas de inflação no Brasil (1999-2012): uma análise institucional. Ensaios FEE, Porto Alegre, v. 34, n. 2, p. 407-438, dez. 2013

SVENSSON, L.E. O. Inflation forecast targeting: implementing and monitoring inflation targets, 1997. European Economic Review, v, 41, pp. 1.111-1.146, 1997a.

SVENSSON, L.E.O. Inflation Targeting: Some Extensions. 1997. NBER working paper no. 5962, $1997 \mathrm{~b}$.

TERRA, Fábio Henrique Bittes. Uma interpretação pós-keynesiana do Regime de Metas de Inflação: poderia a Autoridade Monetária ser capturada pelo sistema bancário? Revista da Sociedade Brasileira de Economia Política, v. 38, p. 108-126, 2014. 